\title{
Peran Penjas Dalam Implementasi Program Full Day School (FDS) Dilihat Dari Tingkat Kehadiran dan Prestasi Belajar Siswa
}

\author{
Januar Abdilah Santoso \\ Pendidikan Olahraga, Fakultas Keguruan dan Ilmu Pendidikan, Universitas Muhammadiyah Kalimantan Timur, \\ Jas970@umkt.ac.id
}

\section{Julianur}

Pendidikan Olahraga, Fakultas Keguruan dan Ilmu Pendidikan, Universitas Muhammadiyah Kalimantan Timur, Julianur@umkt.ac.id

Andy Widhiya Bayu Utomo

Pendidikan Jasmani Kesehatan dan Rekreasi, STKIP Modern Ngawi, andywbu@stkipmodernngawi.ac.id

\begin{abstract}
Abstrak
Tujuan penelitian ini adalah untuk melihat peranan mata pelajaran penjas terhadap implementasi program full FDS terkait tingkat kebugaran jasmani yang berpengaruh terhadap kesehatan, tingkat kehadiran siswa, dan prestasi belajar. Hasil penelitian setelah melewati analisis data menggunakan rumus produk momen menunjukkan beberapa poin penting bahwa: (1) Terdapat hubungan yang signifikan antara kebugaran jasmani dengan tingkat kehadiran siswa dengan $r_{\text {hitung }}(0,424)>r_{\text {tabel }}(0,312)$; (2) Tingkat kehadiran signifikan mempengaruhi prestasi akademik dengan hasil perhitungan $r_{\text {hitung }}(0,350)>r_{\text {tabel }}(0,312)$. Kesimpulan dari hasil penelitian menunjukkan bahwa kebugaran jasmani anak umur 10-12 tahun di SDM 4 Terpadu pada kategori "KURANG". Kebugaran jasmani memberikan konstribusi positif terhadap tingkat kehadiran siswa dan kelancaran program FDS, kemudian tingkat kehadiran siswa berkorelasi positif terhadap prestasi akademik. Pencapaian prestasi akademik dipengaruhi oleh beberapa faktor internal maupun eksternal seperti kondisi kesehatan siswa, kemampuan kognitif, motivasi, fasilitas, metode pembelajaran dan manajemen waktu bermain serta belajar.
\end{abstract}

Kata Kunci :Full Day School, Kebugaran Jasmani, Penjas, Prestasi Belajar

\section{PENDAHULUAN}

Full Day School (FDS) adalah program sekolah yang menyelenggarakan proses belajar mengajar di sekolah selama sehari penuh (Hastuti,2017:197). Adapun pro dan kontra penerapan full day school adalah suatu hal yang tak bisa dihindari karena memang biasanya setiap kebijakan tak lepas dari berbagai tantangan, Setiap kebijakan pasti akan memiliki konsekuensi yang siap untuk ditanggung. full day school tak lepas dari beberapa kelebihan jika diterapkan namun juga memiliki kekurangan.

Menurut Baharudin (2010:225) beberapa kelebihan program full day school seperti; pertama, anak mendapatkan pendidikan umum untuk antisipasi menghadapi perkembangan ilmu pengetahuan. Kedua, anak mendapatkan keterampilan antisipatif terhadap perubahan sosial budaya. Ketiga, bakat anak tersalurkan melalui kegiatan ekstrakurikuler sekolah. Selain Rahem (2017:5) menyampaikan bahwa program FDS efektif membentuk karakter anak, siswa memiliki kesempatan belajar yang lebih banyak, siswa tidak lagi mendapatkan PR karena tugas belajar harus diselesaikan disekolah saja, kegiatan ekstrakurikuler lebih bisa maksimal diterapkan, hari libur lebih banyak. Disisilain FDS juga memiliki beberapa permasalahan seperti yang disampaikan oleh Irma dan Imran (2021) bahwa; 1). Kapasitas otak anak terbatas, 2). Kelelahan dan tingkat konsentrasi cukup rendah, 3). Prasarana dan sarana sekolah yang belum memadai, 4). Kondisi sosial ekonomi setiap peserta didik berbeda-beda, 5). Transportasi disebagian 
daerah belum tersedia. Hal tersebut menjadi faktor-faktor yang perlu dipertimbangkan dalam penerapan program FDS.

Dari kelebihan dan kelemahan diatas peneliti tertarik untuk meneliti salahsatu aspek yang menjadi kekurangan pada program FDS ini. Dengan durasi pertemuan yang cukup panjang setiap harinya, secara tidak langsung pihak sekolah menuntut peserta didik berada pada tingkat kebugaran yang baik. Hasil peneltian Parmo (2014) menyebutkan terdapat korelasi positif antara tingkat kebugaran jasmani dengan prestasi belajar siswa. Sistem cardio-respiratory pada peserta didik dengan tingkat kebugaran jasmani yang tinggi akan membuat sirkulasi darah lancar keseluruh tubuh dan membuat peserta didik bisa lebih lama berkonsentrasi dalam menerima pelajaran. Baik buruknya kebugaran jasmani peserta didik tidak lepas dari peran Pendidikan Jasmani Kesehatan dan Rekreasi sebagai mata pelajaran yang lebih banyak menyajikan materinya pada ranah Psikomotor, yang muaranya menghasilkan bermacam-macam keterampilan gerak dan meningkatnya kualitas kebugaran jasmani. Sejauh ini data tentang tingkat kebugaran jasmani cukup minim dan tidak aktual, sehingga para peneliti cenderung kesusahan pada saat mencari referensi data. Pada penelitian ini, peneliti ingin menyajikan data secara aktual dan faktual sebagai dasar untuk melaksanakan evalusi maupun penelitian lanjutan.

Peneliti melihat pentingnya dilakukan penelitian ini sebab dengan diperolehnya data merupakan senjata yang dapat digunakan untuk melaksanakan proses evaluasi dan perbaikan secara nyata. Rumusan masalah yang ingin dicapai dalam penelitian ini adalah sebagai berikut; (1) Mendapatkan data yang akurat, aktual dan faktual tentang kondisi kebugaran jasmani siswa SD yang mengimplementasikan program FDS, (2) Mengetahui tingkat kehadiran siswa, (3) Mengetahui korelasi antara kondisi kebugaran jasmani dengan tingkat kehadiran siswa. (3) Mengetahui fakta korelasi antara tingkat kehadiran siswa dengan prestasi akademik. Pada penelitian ini dapat dibuat suatu dugaan sementara atau hipotesis bahwa "ada hubungan tingkat kebugaran jasmani dengan sukseknya program full day school".

\section{METODE}

Penelitian ini merupakan penelitian deskriptif dengan pendekatan kuantitatif yaitu penelitian dengan menganalisis data yang di dapatkan dari sampel penelitian kemudian dideskripsikan menggunakan kata-kata, gambar maupun diagram (Sugiyono, 2003:14). Penelitian ini akan dilaksanakan di Sekolah Dasar Muhammadiyah 4 Terpadu yang berlokasi di Jalan KH. Wahid Hasyim/ Alim 1 Rt 28 Sempaja Selatan Samarinda Utara.

Menurut Sugiyono (2008:115), "Populasi adalah wilayah generalisai terdiri atas subyek/subyek yang mempunyai kualitas dan karakteristik tertentu ditetapkan oleh peneliti untuk dipelajari dan kemudian ditarik kesimpulan'. Dalam penelitian ini populasinya adalah semua siswa/siswi Sekolah Dasar Muhammadiyah 4 Terpadu yang berumur 10-12 tahun. Sampel Penelitian merupakan sebagian jumlah dari populasi yang mewakili karakteristik populasi tersebut (Sugiyono, 2008:116). Pengambilan sambil jika dibawah 100 lebih baik di ambil secara keseluruhan, dan jiaka populasi cukup besar bisa diambil 10-15\% atau 20-55\% dengan mempertimbangkan kemampuan dan biaya penelitian.

Teknik sampling pada penelitian ini menggunakan teknik pengambilan sampel proporsional random sampling. Ramdom artinya mengambil sampel dengan cara acak, dan proporsional adalah memilih sampel dengan mempertimbangkan unsur-unsur atau kategori dalam populasi penelitian (Sugiyanto, 2003:74-78). Dengan demikian, dapat diartikan 
bahwa proporsional random sampling adalah cara pemilihan sampel secara acak dengan memperhatikan unsur-unsur tertentu dalam populasi penelitian. Cara pengambilan sampel dalam penelitian ini memilih semua siswa siswi yang berumur 10 sampai 12 tahun pada seluruh kelas yang ada di SD Muhammadiyah 4 Terpadu Samarinda. Kemudian jumlah total siswa umur 10-12 tahun diambil $20-55 \%$ untuk dijadikan sampel penelitian. Sampel pada penelitian ini berjumlah 40 siswa dari kelas 5 dengan rincian 20 putra dan 20 puteri. Pengambilan sampel disesuaikan dengan kemampuan peneliti, pembiayaan dan keluasan waktu penelitian.

Arikunto (2002:136) "Metode penelitian merupakan cara yang digunakan oleh peneliti dalam pengumpulan data penelitianya". Dapat diartikan bahwa metode penelitian merupakan cara yang digunakan untuk mengumpulkan data yang diperlukan dalam penelitian. Data diambil dari tes kebugaran jasmani Indonesia dengan pedoman baku batrai tes kebugaran jasmani Indonesia (TKJI). TKJI memiliki 2 kategori berdasarkan jenis kelamin (laki- laki dan perempuan) yang dikelompakkan menjadi 4 kelompok rentang umur (umur 6-9, 10-12, 1315 dan 16-19).

Instrument penelitian menggunakan rangkaian tes kebugaran jasmani yang didalamnya terdapat lima jenis kegiatan fisik. Rangkaian tes fisik tersebuh secara rinci yaitu lari sprint, gantung siku, baring duduk, vertical jump dan lari jarak menengah (Depdiknas: 2003). Data yang telah didapat akan diberi nilai sesuai dengan kategori jenis kelamin dan umur kemudian keseluruhan hasil dari rangkaian tes akan diklasifikasikan berdasarkan norma penilaian TKJI. Dibawah ini merupakan kategori, norma penilaian dan rangkaian tes kebugaran jasmani Indonesia sesuai klasifikasi yang sesuai untuk anak 10-12 tahun.

Setelah semua data mentah TKJI terkumpul, kemudian diolah menggunakan tabel norma penilaian TKJI diatas sesuai dengan jenis kelamin. Data lain yang didapat adalah data nilai akademik siswa dan rekapitulasi kehadiran selama setengah semester. Untuk menghitung korelasi tingkat kebugaran siswa dengan prestasi belajar menggunakan rumus korelasi produk momen dengan taraf $\alpha=5 \%$.

\section{HASIL DAN PEMBAHASAN}

Setelah melalui perhitungan data kasar TKJI, analisis data pada nilai hasil belajar siswa (NHBS) serta kehadiran siswa dapat di tampilkan sebagai berikut:

Tabel 1. Hasil TKJI, Kehadiran dan NHBS

\begin{tabular}{|c|c|c|c|c|}
\hline $\begin{array}{c}\mathbf{N} \\
\mathbf{o}\end{array}$ & JK & TKJI & Kehadiran & NHBS \\
\hline 1 & $\mathrm{~L}$ & 10,95 & 94,65 & 82,54 \\
\hline 2 & $\mathrm{P}$ & 11,75 & 96,18 & 83,25 \\
\hline & Avg & 11,35 & 95,42 & 82,90 \\
\hline
\end{tabular}

\section{Tingkat Kebugaran Jasmani}

Pada tabel 1 menunjukkan bahwa hasil Tes Kebugaran Jasmani siswa laki-laki dengan rata-rata nilai 10,95 termasuk dalam kategori "KURANG" (K), begitu juga dengan rata-rata hasil TKJI siswi perempuan dengan nilai 11,75 termasuk dalam klasifikasi "KURANG". Hasil TKJI antara siswa laki-laki dan perempunan menunjukkan bahwa tingkat kebugaran jasmani anak perempuan lebih baik dari pada anak lakilaki. Kesimpulan dari hasil TKJI anak-anak umur 10 - 12 tahun SD Muh 4 terpadu secara umum kondisi kebugaran jasmani siswa pada kategori "KURANG" dengan nilai rata-rata 11,35. Dibawah ini merupakan gambar rincian prosentase klasifikasi hasil TKJI siswa siswi SD Muh 4 Terpadu dengan perbandingan antara siswa laki-laki dan perempuan. 


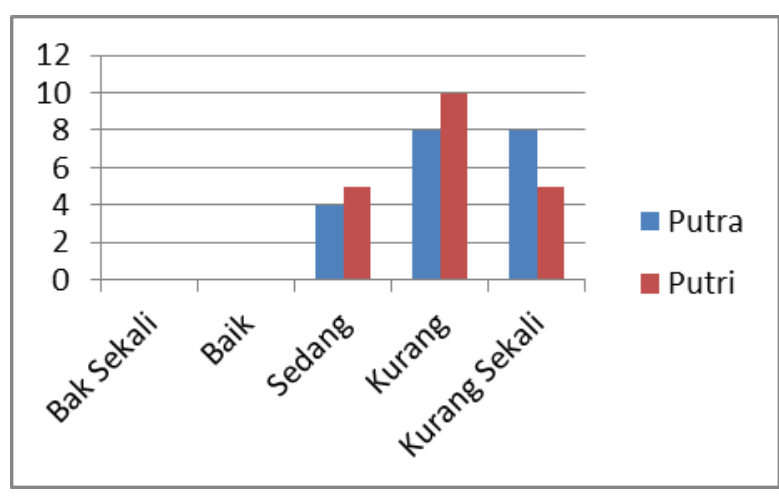

Gambar 1. Diagram Hasil TKJI

Menurut Milka Noviananda Hardy (2016) hal ini bisa saja terjadi karenakan usia kematangan antara anak laki-laki dan perempuan berbeda. Kematangan anak perempuan datang lebih awal dibandingkan dengan anak laki-laki. Wiwit (2021) juga menjelaskan bahwa ciri-ciri perkembangan anak usia 6-12 tahun tingi badan mengalami kenaikan 2-3 inci pertahun pada perempuan usia 11 tahun dengan tinggi 58 inci dan pria 57,5 inci. Berat badan anak usia 11 tahun jenis kelamin perempuan seberat 88,5 pon dan lakilaki dengan berat 85,5 pon. Hal-hal tersebut dapat menjadi dasar mengapa hasil tes kebugaran jasmani anak laki-laki lebih rendah dibandingkan anak perempuan pada usia 10-12 tahun.

Disisi lain perbedaan kualitas kebugaran jasmani siswa dapat dipengaruhi oleh berbagai faktor seperti aktivitas yang dilakukan, model latihan dan media yang digunakan siswa (Jusuf :2021).

\section{Tingkat Kehadiran Siswa}

Persentase rata-rata kehadiran siswa selama 3 (tiga) bulan terakhir dilihat dari rekam jejak absensi menunjukkan bahwa tingkat kehadiran siswi putri lebih besar dibandingkan tingkat kehadiran siswa putera dengan rincian 94,65\% kehadiran siswa laki-laki dan 96,18\% kehadiran siswi perempuan. Total kehadiran seluruh siswa sebesar $95,42 \%$ dari total 72 hari aktif selama 3 bulan. Dari bukti absensi kelas menunjukkan bahwa siswa-siswi yang tidak masuk sekolah diakibatkan karena sakit.

Agus Yudiawan (2019) menyampaikan bahwa tingkat kehadiran siswa dipengaruhi oleh beberapa faktor yaitu faktor internal dan eksternal. Faktor internal meliputi motivasi diri, disiplin diri, kesehatan dan persepsi akan kehadiran. Sedangkan faktor eksternal meliputi lingkungan keluarga, lingkungan pergaulan dan lingkungan sekolah.

Mulyasa (2011) juga menyampaikan bahwa motivasi diri sangat berperan penting sebagai motor penggerak diri agar siswa mau dengan suka rela berangkat ke sekolah. Namun faktor lain juga berperan serta mempengaruhi kehadiran seperti kesehatan jasmani dan rohani. Kesehatan jasmani meliputi kebugaran dimana kebugaran adalah pondasi utama siswa-siswa dapat mengikuti pelajaran dengan baik dari awal hingga akhir jam pelajaran.

Menurut data penelitian yang tersaji, prosentase kehadiran siswi putri lebih besar dibandingkan siswa putra, hal ini kemudian dapat di simpulkan bahwa tingkat kebugaran siswi putri lebih yang baik dibandingkan putera mempengaruhi tingkat kehadiran disekolah.

\section{Prestasi Belajar Siswa}

Prestasi belajar dapat dilihat dari nilai hasil belajar Siswa (NHBS). Data dari nilai ini diambilkan dari nilai rata-rata penilaian akhir semester siswa. Dari data penelitian yang diperoleh menunjukkan bahwa NHBS siswi perempuan lebih besar di bandingkan dengan nilai siswa laki- laki. Rincian nilai rata-rata siswa laki-laki sebesar 82,25 dan siswi perempuan sebesar 83,25 . Nilai rata-rata dari keseluruhan siswa adalah 82,90. Jika dilihat dari tabel 1 diatas maka secara umum dapat di simpulkan bahwa nilai akademik ini dipengaruhi oleh tingkat kebugaran jasmani yang baik dan tingkat kehadiran siswa yang tinggi. 
Korelasi Antara Kebugaran Jasmani dan Kehadiran siswa

Setelah melewati perhitungan kasar, nilai tiap komponen dianalisis menggunakan rumus produk momen sederhana (rumus pearson) pada lembar kerja microsoft exel. Hasil rekapitulasi dari komponen-komponen yang diteliti adalah sebagai berikut:

Tabel 2. Korelasi TKJI-Kehadiran-NHBS

\begin{tabular}{|c|c|c|c|c|}
\hline No & POIN & Nilai TKJI & Kehadiran & NHBS \\
\hline 1. & Nilai Max & 17 & 88.21 & 100 \\
\hline 2. & Nilai Min & 7 & 76.50 & 90.28 \\
\hline 3. & Average & 11.350 & 82.90 & 95.42 \\
\hline 4. & $\mathrm{SD}$ & 2.578 & 2.38 & 3.16 \\
\hline 6. & $\begin{array}{c}r_{T K J I} \& \\
\text { Kehadira } \\
n\end{array}$ & 0.424 & & \\
\hline 7. & $\begin{array}{c}r_{\text {Kehadira }} \\
n \& N H B S\end{array}$ & 0.350 & & \\
\hline
\end{tabular}

Tingkat kebugaran yang baik mempengaruhi kualitas kesehatan siswa. Hal tersebut juga dapat dibuktikan dengan hasil penelitian yang menunjukkan bahwa tingkat kebugaran siswa berkorelasi positif dengan tingkat kehadiran siswa. Hasil perhitungan menunjukkan bahwa $r_{\text {hitung }}(0,424)>r_{\text {tabel }}(0,312)$ yang berarti ada hubungan yang signifikan antara tingkat kebugaran jasmani dengan tingkat kehadiran siswa di sekolah. Akhmad Mustofa (2020) menyampaikan bahwa tubuh yang bugar merupakan salah satu indikator dari kesehatan siswa dan kehadiran siswa merupakan representasi dari kesehatan siswa itu sendiri. Kesehatan didapatkan dari aktivitas fisik maupun olahraga dimana olahraga anak-anak ini berbentuk permainan dengan teman sebaya dan kegiatan pada mata pelajaran penjaskes.

Pada saat melakukan aktivitas fisik bersama-sama, terdapat interaksi dengan sesama teman, tertawa bersama dan bersenang-senang. Hal tersebut dapat meningkatkan imunitas tubuh, dimana imunitas tubuh ini adalah faktor penting untuk menjaga kesehatan siswa (Adiba: 2019). Larasati (2016) juga menegaskan bahwa stress dapat menurunkan imunitas tubuh yang artinya jika anak-anak sering beraktivitas bersama teman dengan cara bermain maka akan menurunkan tingkat stress kemudian dapat meningkatkan kesehatan sehingga siswa yang sehat dan bahagia ini dengan senang hati akan berangkat ke sekolah.

Kesimpulan akhir pada bagian ini adalah perlunya membangun tingkat kebugaran jasmani siswa untuk meningkatkan persentase kehadiran siswa. Dengan tingkat kebugaran jasmani yang baik maka daya tahan tubuh siswa juga baik, hal ini akan membuat siswa tidak akan mudah terserang penyakit. Pada akhirnya dengan kondisi kebugaran jasmani yang baik maka akan meningkatkan grafik kehadiran siswa kesekolah

\section{Korelasi Antara Kehadiran dan Prestasi Belajar}

Hubungan antara kehadiran dengan prestasi akademik pada siswa kelas 5 SD Muh 4 terpadu menunjukan adanya hubungan yang signifikan, dengan hasil $r_{\text {hitung }}(0,350)>$ $r_{\text {tabel }}(0,312)$ maka dapat disimpukan bahwasanya kehadiran memiliki hubungan yang erat kaitanya dengan perolehan prestasi akademik.

Kehadiran siswa dapat mempengaruhi prestasi belajar siswa karena dipengaruhi oleh faktor internal dan eksternal. Faktor internal meliputi motivasi, kesehatan dan intelegensi (Ade: 2019). Ketika siswa hadir mengikuti pelajaran maka siswa akan mendapatkan cukup informasi terkait materi-materi yang di sampaikan sehingga berguna untuk menyelesaikan ujian-ujian yang diberikan oleh guru pada saat penilaian akhir sekolah.

Agus Yudiawan (2019) juga menemukan fakta pada penelitianya bahwa siswa yang memiliki banyak absen juga cenderung memperoleh hasil belajar yang lebih rendah dibandingkan dengan siswa yang memiliki sedikit absen di dalam satu semester. Kemudian faktor-faktor penyebab siswa absen adalah karena sakit, peraturan sekolah masih longgar 
untuk menindak lanjuti siswa yang absen, motivasi anak yang rendah dan penyampaian materi oleh guru yang monoton (Imam Supriyadi: 2018).

\section{PENUTUP}

\section{Simpulan}

Dari hasil penelitian yang di peroleh ratarata tingkat kebugaran jasmani siswa-siswi SD Muh 1 Terpadu usia 10-12 tahun pada kategori "Kurang" dimana rata-rata kebugaran jasmani siswi putri lebih baik dibandingkan dengan siswa putra. Persentase rata-rata kehadiran siswa selama 3 (tiga) bulan terakhir menunjukkan bahwa tingkat kehadiran siswi putri lebih besar dibandingkan tingkat kehadiran siswa putra dengan rincian 94,65\% kehadiran siswa laki-laki dan $96,18 \%$ kehadiran siswi perempuan. Total kehadiran seluruh siswa sebesar 95,42\% dari total 72 hari aktif selama 3 bulan. Dari bukti absensi kelas menunjukkan bahwa siswa-siswi yang tidak masuk sekolah diakibatkan karena sakit. Siswa-siswa yang memiliki kecenderungan sedikit absen juga menunjukkan prestasi belajar yang lebih baik dibandingkan dengan siswa yang memiliki banyak absen.

Terdapat hubungan yang signifikan antara tingkat kebugaran terhadap tingkat kehadiran siswa dikarenakan tingkat kebugaran berkaitan dengan aspek kesehatan fisik dan mental dimana kesehatan fisik dapat di ibaratkan sebagai bodi motor dan kesehatan mental sebagai mesin penggerak. Jika siswa dengan kesehatan mental dan fisiknya baik, pastinya memiliki motivasi yang besar untuk datang ke sekolah untuk belajar bersama teman-temanya.

Tingkat kehadiran siswa juga berkorelasi positif terhadap prestasi belajar siswa dikarenakan siswa yang rajin datang dan belajar disekolah memiliki waktu yang cukup untuk mendapatkan pelajaran serta bimbingan dari guru, dan dapat berdiskusi dengan teman untuk memecahkan masalah yang telah disiapkan oleh guru sebelumnya. Hal ini pastinya tidak akan didapatan oleh siswa yang memiliki banyak absen.

Penjaskes sebagai mata pelajaran yang dapat memfasilitasi siswa untuk mengolah jasmani dan mental ini memiliki peran yang sangat penting didalam mensukseskan program FDS yang di terapkan oleh pihak sekolah. Dengan mengoptimalkan mapel penjas, maka tingkat kebugaran siswa akan meningkat, dimana tingkat kebugaran ini juga akan menekan tingkat absen siswa. Dengan tingkat kebugaran yang baik maka tingkat kehadiran siswa meningkat dan prestasi belajar siswa pastinya akan lebih baik lagi.

\section{Saran}

Bagi guru penjas disekolah hendaknya memaksimalkan waktu mata pelajaran penjas untuk mengolahragakan siswa agar siswa dapat bergerak aktif dalam rangka meningkatkan kebugaran jasmaninya. Kemudian adakan tes kebugaran jasmani secara rutin sehingga pihak sekolah mendapatkan gambaran dan data yang actual mengenai perkembangan siswa dari sisi kesiapan jasmani dan mentalnya.

Bagi pihak sekolah kami sarankan untuk mendukung program rutin tes kebugaran jasmani yang dikelola bersama antara guru bimbingan konseling dan guru penjas dengan menyiapkan sarana dan prasarana.

Bagi peneliti lain yang memiliki ketertarikan untuk melakukan tes kebugaran jasmani Indonesia pada rentang usia 10-12 tahun untuk memperhatikan pada bagian uji kekuatan otot lengan gantung badan siku tekuk, karena kami menemukan bahwa banyak anakanak yang menjadi sampel kami mendapatkan poin yang sangat kurang disini, sehingga membuat data kurang baik.

\section{DAFTAR PUSTAKA}

Ade dan Imran. (2019). Dampak Penerapan Full Day School Pada Pembelajaran Siswa di 
SMP Negeri 14 Palu. Jurnal Edu Civic. 5 (1), 46-53.

Adiba, F. N. (2019). Analisis Hubungan Tertawa Terhadap Kadar Endorfin Berkaitan dengan Fungsi Imunitas Tubuh. doi.org/10.31227/osf.io/5qy62

Agus Yudiawan. (2019) Analisis Korelasi Tingkat Absensi Dengan Hasil Belajar Siswa MTs Sains al-Gebra Kota Sorong Papua Barat. Jurnal Kependidikan. 11(2), 353-373.

Arikunto, S. 2002. Metodologi Penelitian. Yogyakarta: Bina Aksara.

Baharuddin. (2010). Pendidikan dan Psikologi Perkembangan. Jogjakarta: Ar-Ruzz MediaIrma.

Depdiknas. 2003. Undang-undang RI Nomor 20 Tahun 2003, Tentang Sistem PendidikanNasional.

E. Mulyasa. (2011). Manajemen \& Kepemimpinan Kepala Sekolah. Jakarta: Bumi Aksara.

Hastuti, Ismail M. (2017). Implementasi Pendidikan Karakter dalam Sistem Full Day School di MIM Unggulan Kota Gorontalo. Jurnal Ilmiah AL- Jauhari (JIAJ). 2(2), 195-210.

Hardy, M.N., Saraswati, L.D., Udiyono, Ari. (2016). Gambaran Perkembangan Pubertas Dan Perbedaan Usia Awal Pubertas Pada Siswa-Siswi Sekolah Dasar (Studi Di Kecamatan Semarang Tengah Kota Semarang). Jurnal Kesehatan Masyarakat. 4(1).

Irma, D.I, Imran, Purwati, Rahmiati. 2021. The Effectiveness Of Google Classroom In Theaching Ebglish During Covid-19 At SMAN 1 M.Payed doi:10.33474/jreall.v2i1.9518

Larasati, R. (2016). Pengaruh stress pada Kesehatan jaringan periodontal. Jurnal Skala Husada. The Journal of Health, 13(1), 81-89.

Mustofa, J., Suhartatik, N. (2020). Meningkatkan Imunitas Tubuh Dalam Menghadapi Pandemi Covid-19 Di Karangtaruna Kedunggupit, Sidoharjo, Wonogiri, Jawa Tengah. Jurnal Pengabdian Masyarakat Berkemajuan. 4(1). 2614-526X.
Rahem, Zaitur. (2017). Dampak Sosial pemberlakuan Full Day School (Menimbang Mafsadat-Maslahat Permendikbud 23/2017 dan Perpres 87/2017). Al- Murabbi: Jurnal Pendidikan Agama Islam. 3(1), 1-12.

Santoso, J.A., Jusuf, J.B.K., dkk. (2021). Pengembangan Model Latihan Kombinasi Berbasis Flip Book Maker Pada Pemain Sepak Bola Tingkat Intermediate. Jurnal Pendidikan Modern. Vol 6, No 2. Januari 2021. doi: 10.37471/jpm.v6i2.198

Sugiyanto, 2003. Metode Penelitian Bisnis, Bandung: Alfabeta.

Sugiyono. 2003. Metode Penelitian. Bandung: Alfabeta.Sugiyono. 2008. Metode Penelitian Kuantitatif Kualitatif dan R\&D. Bandung: ALFABETA

Supriyadi, Imam. (2018). Studi Kasus Hubungan Tingkat Kehadiran Siswa Terhadap Prestasi Belajar Biologi DI SMA Negeri 2 AIMAS. Biolearning Journal. 5(1):14-22. Doi: 10.36232/jb.v5i1.263

Winarsih, W.E. (2021). Perkembangan Fisik Anak, Problem Dan Penanganannya. Atthiflah: Journal of Early Childhood Islamic Education. Volume 8, Edisi 1, Januari 2021; p-Issn: 2580-1864; e-Issn: 2722-1210; 55-68 